\title{
Escherichia coli, but not Staphylococcus aureus triggers an early increased expression of factors contributing to the innate immune defense in the udder of the cow
}

\author{
Wolfram PETZL ${ }^{1}$, Holm ZERBE ${ }^{1}$, Juliane GÜNTHER ${ }^{2}$, Wei YANG ${ }^{2,4}$, \\ Hans-Martin SEYFERT ${ }^{2}$, Gerd NÜRNBERG ${ }^{2}$, Hans-Joachim SCHUBERTH ${ }^{3 *}$ \\ ${ }^{1}$ Clinic for Ruminants, Ludwig-Maximilians-University, Munich, Germany \\ ${ }^{2}$ Research Institute for the Biology of Farm Animals, Dummerstorf, Germany \\ ${ }^{3}$ Institute of Immunology, University of Veterinary Medicine, Hannover, Germany \\ ${ }^{4}$ Present address: Duke University, Durham, North Carolina, USA
}

(Received 3 March 2007; accepted 7 November 2007)

\begin{abstract}
The outcome of an udder infection is influenced by the pathogen species. We established a strictly defined infection model to better analyze the unknown molecular causes for these pathogen-specific effects, using Escherichia coli and Staphylococcus aureus strains previously asseverated from field cases of mastitis. Inoculation of quarters with $500 \mathrm{CFU}$ of E. coli $(n=4)$ was performed $6 \mathrm{~h}, 12 \mathrm{~h}$, and $24 \mathrm{~h}$ before culling. All animals showed signs of acute clinical mastitis $12 \mathrm{~h}$ after challenge: increased somatic cell count (SCC), decreased milk yield, leukopenia, fever, and udder swelling. Animals inoculated with $10000 \mathrm{CFU}$ of $S$. aureus for $24 \mathrm{~h}(n=4)$ showed no or only modest clinical signs of mastitis. However, $S$. aureus caused clinical signs in animals, inoculated for $72 \mathrm{~h}-84 \mathrm{~h}$. Real-time PCR proved that $E$. coli inoculation strongly and significantly upregulated the expression of $\beta$-defensins, TLR2 and TLR4 in the pathogen inoculated udder quarters as well as in mammary lymph nodes. TLR3 and TLR6 were not significantly regulated by the infections. Immuno-histochemistry identified mammary epithelial cells as sites for the upregulated TLR2 and $\beta$-defensin expression. $S$. aureus, in contrast, did not significantly regulate the expression of any of these genes during the first $24 \mathrm{~h}$ after pathogen inoculation. Only $84 \mathrm{~h}$ after inoculation, the expression of $\beta$-defensins, but not of TLRs was significantly ( $>20$ fold) upregulated in five out of six pathogen inoculated quarters. Using the established mastitis model, the data clearly demonstrate a pathogen-dependent difference in the time kinetics of induced pathogen receptors and defense molecules.
\end{abstract}

\section{toll-like receptor / mastitis / beta-defensin / mammary epithelial cell}

\section{INTRODUCTION}

Mastitis still represents one of the major diseases in dairy cattle [27] causing high economic losses. Bacteria are the main mastitis pathogens, followed in relevance by yeasts and fungi.

Two of the most important bacterial mastitis pathogens are Staphylococcus aureus and Escherichia coli [4]. The courses of the udder inflammations may vary significantly between these pathogens. Intramammary infec-

* Corresponding author:

hans-joachim.schuberth@tiho-hannover.de tions with $E$. coli very often result in an acute mastitis with severe clinical consequences [3]. Infected animals may die or recover from the disease within days [47]. In contrast, mastitis caused by $S$. aureus is mostly less severe but can eventually turn into a chronic infection with a lifelong persistence of the bacteria [34, 49]. Some $S$. aureus infections may also cause subclinical mastitis with no apparent clinical symptoms (e.g. swelling of the udder, milk flakes, fever) and only intermittent detection of bacteria in milk paired with elevated somatic cell counts (SCC) [33]. 
A significant number of studies used experimentally infected udders to study the events after pathogen contact [23, 24,31].

However, these studies varied considerably in the applied standards regarding the animals used, their history of mastitis, and status of SCC at the time of infection. SCC values ranged from $<20000$ [16] to $<600000$ [12] before infection. The time of the experimental infection differed between $72 \mathrm{~h}$ [26] and 48 days [39] for both bacterial species, sometimes with repeated infections of the animals [26]. The infection dose varied for both $S$. aureus and $E$. coli between 50 and about 10000 colony forming units (CFU per udder quarter) $[23,55]$. In addition, animals were not always prescreened for a prolonged absence of pathogenic bacteria within the udder prior to experimental infections [40]. Thus, results of the different model systems are difficult to compare.

The host responses induced early during infection may be crucial determinants for the different pathogenesis after infection with $E$. coli or $S$. aureus. Knowledge about these responses is still rather limited [3,33]. Proper recognition of the pathogen by the host represents quite likely a key event in the pathogenesis of infectious diseases [32].

Recognition of pathogens is mediated by cellular pattern recognition receptors recognizing pathogen-associated molecular pattern (PAMPs) such as lipopolysaccharide (LPS) from E. coli or lipoteichoic acid (LTA) from $S$. aureus. The most important PRR group is represented by the transmembrane toll-like receptors (TLRs), which are specialized for the recognition of distinct PAMPs (e.g. LPS by TLR4 or LTA by TLR2). Overall, a total of 13 different TLRs are described for mouse and man [22]. In cattle, currently sequences for ten TLRs are described [59]. We have previously demonstrated in udder tissues of cows with clinical mastitis, that bovine TLR2 and TLR4, but not TLR9 are selectively up-regulated in both E. coli and S. aureusinfected animals [13].

Ligand binding activates TLRs and triggers the expression of regulatory cytokines and other mediators [52] which orchestrate the subsequent immune responses as well as the modulation of recruited effector cells.

Bacterial infections elicit in the host the synthesis of bactericidal and fungicidal factors, like $\beta$-defensins. Expression of $\beta$-defensins can be induced by pathogens $[10,11]$ and it has been shown that expression of human $\beta$-defensin- 2 depends on TLR2- and TLR4-mediated nuclear factor kappa B (NF- $\mathrm{B})$-activation [5, 57]. In cattle, $16 \beta$-defensin genes and two pseudogenes are described [35]. Defensins are cysteine- and arginine-rich peptides (cationic amphiphilic 38-42 amino acids) which can act in an oxygen-independent way $[39,63]$. Especially, because of low oxygen pressure in infected tissues, oxygen-independent mechanisms leading to bacteriolysis seem to be very important [30]. Defensins are synthesized predominantly in epithelial cells and neutrophilic granulocytes where they make up to $15 \%$ of total cytoplasmatic protein [6]. Previously, we demonstrated by in situ hybridization that alveolar epithelial cells in the udder are the dominant location of $\beta$-defensin-5 (BNBD5) expression in the inflamed udder [13]. We also showed that $\mathrm{NF}-\kappa \mathrm{B}$, eventually as delivered by activated TLR-receptors, is a necessary, but not the sufficient component for $\beta$-defensin expression in the bovine MEC [61].

Molecular mechanisms underpinning the escape of subclinical mastitis causing pathogens, like S. aureus, from the host's immune defense are basically unknown. They might include a pathogen species related inefficiency to mount an adequate immune response in the udder, indicating an inappropriate alert of the innate immune system. The infection-associated regulation of factors contributing to the innate immune defense in the udder is not well analyzed.

It is largely unknown, how rapid the expression of bovine TLRs and bactericidal $\beta$-defensin peptides is modulated after an experimental udder infection with either $E$. coli or $S$. aureus, and if the time course and the extent of this induction is influenced in a pathogen-specific fashion.

Thus, this study had two goals. On the one hand, we wanted to establish a standardized 
and quite stringent animal model for acute and subclinical mastitis, and characterize clinical parameters elicited by our model pathogens. This model should be useful for subsequent systematic experimental analyses of pathogenspecific differential activation of the immune defense in the udder. On the other hand, we wanted to compare the impact of an E. coliversus $S$. aureus-caused mastitis on the time course and the extent of activation of factors contributing to the innate immune defense in the udder. Here, we focused on $\beta$-defensin and TLR expression.

\section{MATERIAL AND METHODS}

\subsection{Animals}

The trial included 14 German Holstein cows in the middle of their first lactation (aged between 2630 months, 3 to 5 months post partum) and was conducted under the approval of the ethics committee of the regional government in Hannover, Germany (No. 509.6-42502-03/678). Animals were kept at the University of Veterinary Medicine (Hannover, Germany), and never had clinical or subclinical mastitis before. Quarter milk samples of these animals were tested weekly six times pre-trial and on the day of trial to be free from mastitis pathogens and to have less than 100000 somatic cells $/ \mathrm{mL}$. Daily milk yields were between 15 and $25 \mathrm{~L}$. The trial was conducted in four rounds, each including four animals (trials 1-3) or two animals (trial 4). In the first two rounds, two animals were arbitrarily assigned to become inoculated with either E. coli or $S$. aureus. In the third round, four animals were inoculated with $S$. aureus only.

\subsection{Bacteria}

Strain Escherichia coli (E. coli 1303) and Staphylococcus aureus (S. aureus 1027) were isolated from udder secretions of cows with clinical mastitis. Cultivation of bacteria, storage in glycerol stocks, as well as their biochemical characterization was performed in the Institute of Microbiology, University of Veterinary Medicine (Hannover, Germany). E. coli 1303 was positive for indol generation, lysine decarboxylase, methyl red, glucose, gas generation, lactose, adonite, rhamnose, oxidative, and fermentative glucose degradation. S. aureus 1027 was positive for mannite cleavage, clumping factor, and free coagulase. The characterization was performed according to Burkhardt [7]. Bacteria were kept cryo conserved (Mikrobank-system Cryobank $^{\mathrm{TM}}$, Mast Diagnostika, Reinfeld, Germany) for subsequent infections. Inoculum doses were generated as described by Van Oostveldt et al. [54]. Briefly, bacteria were plated on trypticase soy agar and incubated $\left(37^{\circ} \mathrm{C}\right)$ overnight. Several colonies were transferred to a tube of brain heart infusion broth and the tube was incubated for $6 \mathrm{~h}\left(37^{\circ} \mathrm{C}\right)$. A $100 \mu \mathrm{L}$ sample was then transferred to a tube, containing $9.9 \mathrm{~mL}$ trypticase soy broth. After $24 \mathrm{~h}$ the inoculum was prepared using serial dilutions. The desired inoculum was achieved by determination of the OD related to the amount of colony forming units.

\subsection{Experimental pathogen inoculation, milk and blood sampling, tissue sampling}

Cows were synchronized by two injections of Cloprostenol-sodium salt (Estrumate ${ }^{\circledR}$, Prostaglandin- $\mathrm{F}_{2 \alpha} \quad\left(\mathrm{PGF}_{2 \alpha}\right)$-analogue (Essex, Munich, Germany)) in a 12 day interval, to avoid hormonal influences depending on the sexual cycle. Animals were inoculated with bacteria three days after the second $\mathrm{PGF}_{2 \alpha}$-injection during estrus.

The 14 cows were split into three groups of four animals and one group of two animals each, and inoculated intramammary with either $500 \mathrm{CFU}$ E. coli 1303 over 24 h or 10000 CFU S. aureus 1027. After application of 20 I.E. oxytocin (i.v.) the udder was entirely milked out. Teats were cleaned and disinfected with ethanol $(70 \%)$. Bacteria were suspended in $2 \mathrm{~mL} 0.9 \%$ sterile pyrogen free saline, and administered intracisternally through the teat canal.

Animals challenged over $24 \mathrm{~h}$ (trials 1, 2) were inoculated in the front right, hind right, and hind left quarter at $0 \mathrm{~h} \mathrm{(T0),} 12 \mathrm{~h}$ (T12), and $18 \mathrm{~h} \mathrm{(T18)}$ respectively after starting the trial. The front left quarter received $2 \mathrm{~mL}$ sterile saline at T0. Animals challenged over $72 \mathrm{~h}$ or $84 \mathrm{~h}$ were inoculated in both right quarters at $0 \mathrm{~h}$ (T0) after starting the trial. The left quarters received $2 \mathrm{~mL}$ of sterile saline at T0. Every $12 \mathrm{~h}$ (trials 1 to 4), the udder secretion was sampled before regular milking. The first $5 \mathrm{~mL}$ were discarded; the following $10 \mathrm{~mL}$ were used for SCC determination and bacteriology. Another $10 \mathrm{~mL}$ were milked into a tube containing $40 \mathrm{~mL}$ sterile PBS for the flow cytometric cell characterization (see below). Cows were milked at T0 and $\mathrm{T} 12$ just prior to the inoculation, and $24 \mathrm{~h}$ after the trial start (T24). Finally, cows were killed at T24 (trials 1,2), at T72 (trial 3), or T84 (trial 4) with 
a penetrating captive bolt gun followed by exsanguination.

Udder tissue samples and lymph node samples were collected aseptically from slaughtered cows within 5 to 10 min after killing as described [56].

\subsection{Clinical score and laboratory parameters}

Three weeks before pathogen inoculation, milk yield, California mastitis test (CMT), food intake, and body temperature of each animal were documented twice daily. Quarter milk samples for determination of the SCC and for bacteriological examination were collected weekly. The somatic cell count was determined using the Fossomatic 360 (FOSS Electric, Hillerod, Denmark) cell counter as described [37]. Bacterial levels were determined by the Institute for Animal Health (Ahlem, Germany) by plating $10 \mu \mathrm{L}$ of quartermilk samples on Columbia sheep blood agar. After incubating overnight at $37^{\circ} \mathrm{C}$, the plates were analyzed and the number of bacteria was counted semiquantitatively: 1-20 CFU were classified as low grade (+), 21-200 CFU as middle grade $(++)$, and > $200 \mathrm{CFU}$ as high grade $(+++)$. No animal showed fever, increased SCC, or alteration in milk during this pre-infection period, and the milk was free from mastitis pathogens. The clinical status was obtained after measuring and scoring body temperature, milk yield, milk appearance, udder consistency after palpation, and the general condition of the animals. Changes in those parameters were classified on a scale from 0 to 3 . Red and white blood cell counts as well as differential counts were determined before and at every time point during experimental infection. Blood was taken from the vena jugularis aseptically using EDTA- vacutainers (Becton-Dickinson, Heidelberg, Germany).

\subsection{Flow cytometric milk cell analysis}

Milk samples (10 mL in $40 \mathrm{~mL}$ PBS) were kept on ice before processing. After centrifugation (400 $\times g, 10 \mathrm{~min}, 4{ }^{\circ} \mathrm{C}$ ), fat and skimmed milk were removed. The cell rich sediment was suspended in $50 \mathrm{~mL}$ PBS, centrifuged $(400 \times \mathrm{g}, 10 \mathrm{~min}$, $4{ }^{\circ} \mathrm{C}$ ) and finally the cells were suspended in $1 \mathrm{~mL}$ PBS. After adding propidium iodide $(2 \mu \mathrm{g} / \mathrm{mL}$ final) and acridine orange solution $(2.5 \mathrm{pg} / \mathrm{mL}$ final $)$, the cells were acquired with a FACScan ${ }^{\circledR}$ (Becton Dickinson) cytometer after setting a live gate on green fluorescing particles. The relative proportions of viable cellular subpopulations were determined after gating on propidium iodide-negative events.
Neutrophils, large cells and lymphoid cells were identified in forward versus side scatter dotplots based on their morphological characteristics. Flow cytometric data were analyzed with the software WinMDI (version 2.8) ${ }^{1}$.

\subsection{Pathology and immunohistology}

After slaughtering, udder tissue, regional and peripheral lymph nodes were macroscopically checked for prominent alterations and tissue samples were analyzed by histopathology after H\&E staining. Tissue samples were collected aseptically from slaughtered cows within 5 to $10 \mathrm{~min}$ after killing. A piece of tissue $(5 \times 5 \times 5 \mathrm{~cm})$ was removed from a deeper area of the udder quarter, $10 \mathrm{~cm}$ dorsal of the milk cistern. After changing instruments, a smaller tissue piece $(2 \times 2 \times 2 \mathrm{~cm})$ was gained out of the center of the first one and served as original material for all further analyses. Immuno-histochemistry was used to visualize the expression of lingual antimicrobial peptide (LAP) and TLR2 in serial sections $(7 \mu \mathrm{m})$ from formalin fixed and paraffin-embedded blocks of uninfected control or $24 \mathrm{~h}$ infected quarters. After dewaxing and deparaffinisation and rehydration the sections were taken through a heat induced epitope retrieval (HIER) procedure to reverse the formalin caused cross linking of epitopes. The slides were immersed into $0.1 \mathrm{M}$ sodium citrate $(\mathrm{pH} 6.0)$ and heated to $125{ }^{\circ} \mathrm{C}$ for $5 \mathrm{~min}$ in a steam pot. After slowly $(\sim 50 \mathrm{~min})$ cooling to room temperature the slides were rinsed in water $(3 \times 5 \mathrm{~min}$, each $)$ and subsequently immersed into PBS. The polyclonal anti-LAP antiserum was kindly provided by Drs Molenaar and Wheeler (AgResearch, Hamilton, New Zealand). In rabbits, we established an antiserum against a recombinant expressed truncated bovine TLR2. Briefly, a segment of the cDNA encoding the $\mathrm{N}$-terminal 581 amino acid residues of the bovine TLR2 receptor was cloned into the prokaryotic expression vectors pASK-IBA3puls (IBA, Göttingen, Germany) The construction involved the PCR amplification of the respective area from a full length cDNA clone of the bovine TLR2 factor (kindly provided by Thomas Jungi and Dirk Werling, Institute for Immunology, University of Bern, Switzerland). We used the primers TLR2_IBA3f (5'- TCCCGAATTCCCACGTGCTTTGTGGACAGCATG)

\footnotetext{
${ }^{1}$ Trotter, J., free software for the analysis of flow cytometric data, available at ftp://facs.scripps.edu/ [consulted on November 2007].
} 
and TLR2_IBA3r (GTCGACCTCGAGGGACCTTATTGCAGCTCTCAAATTTAAC) to initially amplify almost the entire coding sequence of TLR2, from codon 2 down to the codon of the c-terminal amino acid residue, introducing an EcoRI and a XhoI site at the 5', and 3'termini, respectively. The PCR amplificate comprising $2359 \mathrm{bp}$ of the bovine TLR2-encoding cDNA was cloned into pGEM-Tesay (Promega, Mannheim, Germany). The insert was retrieved via EcoRI and XhoI digestion and cloned into an appropriately digested pASK-IBA3 plus vector, in front of the vector-encoded Streptactin-binding domain. The carboxy-terminally located TIR domain was deleted from the construct, since this domain is highly conserved among TLR-receptors and hence might elicit undesired cross-reacting antibodies. To this end, the construct was Sall digested and religated, shortening the encoded reading frame down to the desired $\mathrm{N}$-terminal 581 aa residues. The expression vector was transfected into $E$. coli XL-1 blue and the $\sim 55 \mathrm{kDA}$ recombinant TLR2 protein was purified from bacterial lysates via affinity chromatography, using a Streptactin domain binding column (IBA), as prescribed by the manufacturer.

Further purification of this crude antigen preparation using preparative Laemmli gelelectrophoresis, antibody production in rabbits and affinity purification and concentration of the TLR2 specific antibodies on antigen-coupled Sepharose columns was essentially as described [42].

Antibodies were applied in blocking solution (1× Roti-Block (Roth, Karlsruhe, Germany); in PBS/T (PBS containing $0.1 \%$ of each, Triton X100, and Tween 20 (Sigma-Aldrich, St. Louis, Mo, USA)). The LAP-antiserum was diluted 1:100, while $15 \mu \mathrm{g} / \mathrm{mL}$ of the affinity column purified TLR2 specific antibody were applied. Bound primary antibodies were visualized with anti-rabbit IgG (whole molecule)-FITC antibody produced in goat (Sigma; diluted 1:160 in PBS/T). Nuclei were counterstained with propidium iodide $(2 \mu \mathrm{g} / \mathrm{mL}$ $\mathrm{PBS} / \mathrm{T}$ ) and labeled sections were examined under a fluorescence microscope (Leica DMRE microscope, Leica, Wetzlar, Germany).

\subsection{Real-time PCR quantization of mRNA- copy numbers}

We used TRIZOL (Invitrogen, Karlsruhe, Germany) for RNA extraction and the LightCycler instrument with the Syber Green plus reagent kit (both from Roche, Basel, Switzerland) for Realtime-PCR quantization of mRNA copy numbers, essentially as described [13]. Oligonucleotide and fluorescence acquisition temperatures during LightCycler measurements are given in Table I. We used an equimolar mixture of two different forward primers for TLR2 measurements, binding to two different 5'-terminal exons of the bovine TLR2. We had found in 5'-RACE amplifications that these may alternatively be spliced to exon 2 (unpublished). The conserved primers referred to as 'multiple-defensins' amplify several of the bovine $\beta$-defensin encoding genes. Cloning and sequencing of amplificates using RNA from infected udders revealed that they amplify mRNAs from the genes encoding BNBD4, BNBD5, another BNBD5-like gene (divergent from BNBD5 by one amino acid substitution), EBD and LAP and another, LAP like gene (data not shown). LAP messages account for $\sim 80 \%$ of all $\beta$-defensin encoding messages in the infected udder. We used our own complete gene characterizations to derive primers for TLR3 and TLR6 measurements (accession numbers AJ812027 and AJ618974 for TLR3 and TLR6, respectively).

\subsection{Statistical analyses}

The clinical scoring of samples was analyzed by a nonparametric paired samples test (Friedman's test) in SPSS 12.0. The quantitative RT-PCR data on the mRNA concentrations for $\beta$-defensins and TLRs were modeled by a repeated measurement model using the procedure 'mixed' of the statistical software package SAS (version 9.1, SAS Institute Inc., Cary, NC, USA). Duration of pathogen presence was considered as a repeated factor. The posthoc tests between different levels of 'duration of pathogen presence' were done by t-tests with a Tukey correction to ensure an experiment wise error rate $\alpha=0.05$. $P$-values of $\leqslant 0.05$ were considered significant. Significances of alterations in milk cell numbers following pathogen inoculation were assessed with an analysis of variance, applying a twofold cross classification. As fixed factors we considered pathogen inoculation (a), time of repeated sampling (b), and the interaction of both (a with b).

\section{RESULTS}

\subsection{Establishment of infection conditions to elicit $E$. coli or $S$. aureus induced mastitis}

A first key objective of this study was to establish clinical parameters occurring after 


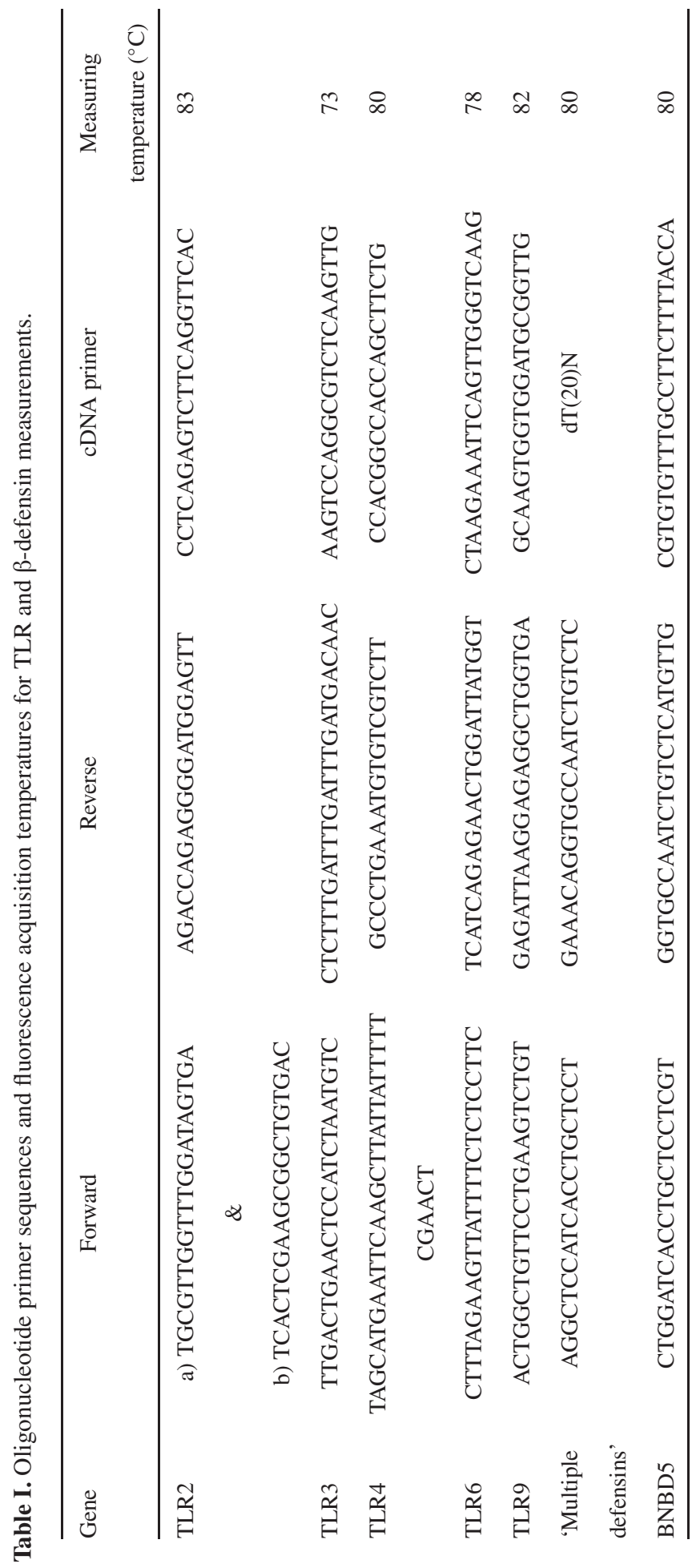


Time of inoculation
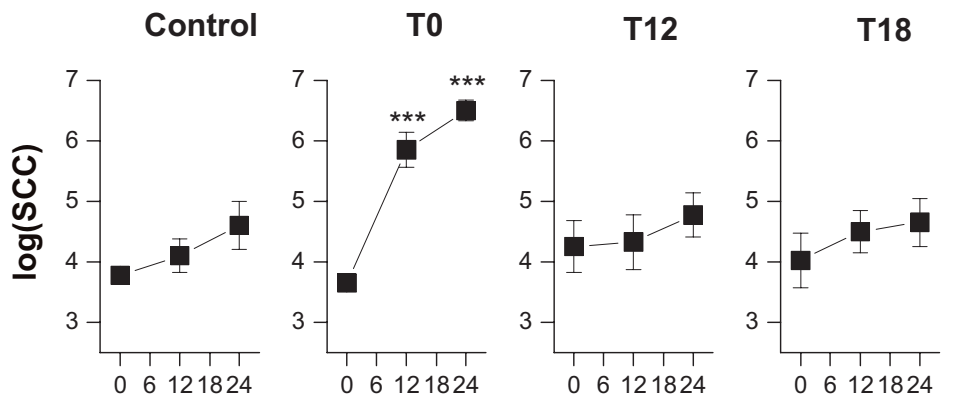

E. coli
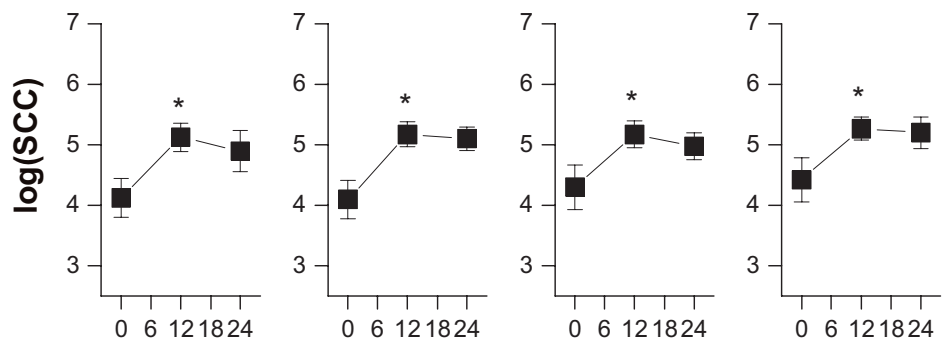

\section{S. aureus}

\section{Hours}

Figure 1. Somatic cell counts in milk of udder quarters after sequential inoculation with E. coli or $S$. aureus Udder quarters were mock inoculated (control), inoculated at T0 for $24 \mathrm{~h}$, at T12 for $12 \mathrm{~h}$ or at T18 for $6 \mathrm{~h}$ (means $\pm \mathrm{SEM}, 4$ cows per group). $* P<0.05 ; * * * P<0.001$.

experimentally inoculated udders of healthy lactating cows with the selected model strains for acute $(E$. coli) or subclinical mastitis (S. aureus). We established first in small experiments the suitable inoculation doses and relevant time courses for the experimental follow up of the infected animals. Regarding E. coli we consistently observed that as little as $500 \mathrm{CFU}$, administered in $2 \mathrm{~mL}$ of sterile saline was enough to elicit a strong cellular response in the inoculated udder quarter within $12 \mathrm{~h}$. Major clinical symptoms, such as udder swelling and elevated counts of somatic cells in milk were restricted to pathogen inoculated udder quarters. All animals inoculated with the E. coli strain 1303 suffered from acute mastitis within 12 h post inoculation. The $S$. aureus strain 1027 , on the contrary, required the administration of $10000 \mathrm{CFU}$ to cause increased cell counts in the milk, in most of the inoculated quarters (Figs. 1 and 2). It became clear that infections caused by this strain can have a longer time lag before they become manifest and cause clear cut clinical signs of infection (Fig. 2). At $72 \mathrm{~h}$ after intra-cisternal application of $S$. aureus, the bacteria could be reisolated from 8 of 12 quarters (Fig. 2). By corollary this implies that the pathogen is not washed (or diluted) out in the course of the regular milkings every $12 \mathrm{~h}$ subsequent to pathogen inoculation. Interestingly, in quarters of cows showing a sharp increase in somatic cell counts $12 \mathrm{~h}$ after inoculation of $S$. $a u$ reus, the strain could be reisolated rather rarely (Fig. 2), suggesting that bacteria are eliminated very fast in case of a strong influx of neutrophilic granulocytes.

These trials showed very clearly that the E. coli infections may only be observed for a period of $24 \mathrm{~h}$, because at that point in time after infection the animals will invariably suffer from acute mastitis. The $S$. aureus strain, on the contrary, will require longer times to firmly establish a successful infection 


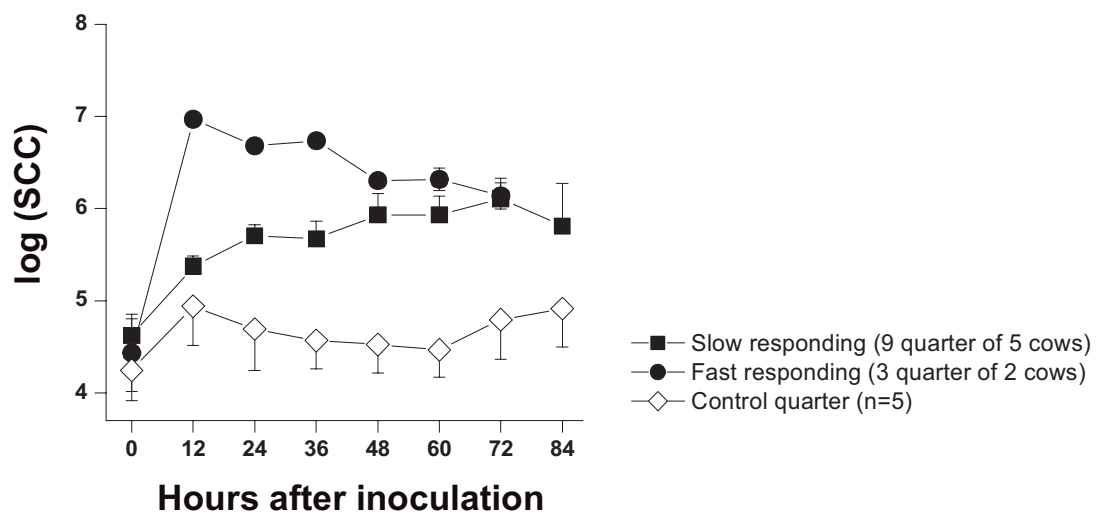

Re-isolation of $S$. aureus from milk of inoculated quarters

\begin{tabular}{lcccccccc}
\hline & \multicolumn{8}{c}{ Hours after inoculation } \\
Quarter & 0 & 12 & 24 & 36 & 48 & 60 & 72 & 84 \\
\hline Fast responding & $0 / 3$ & $0 / 3$ & $0 / 3$ & $0 / 3$ & $0 / 3$ & $0 / 3$ & $1 / 3$ & n.d. \\
Slow responding & $0 / 9$ & $5 / 9$ & $5 / 9$ & $6 / 9$ & $6 / 9$ & $8 / 9$ & $7 / 9$ & $4 / 9$
\end{tabular}

Figure 2. Somatic cell counts in milk of udder quarters after inoculation with $S$. aureus for up to $84 \mathrm{~h}$. Quarters of cows with less than 100000 cells $/ \mathrm{mL}$ were inoculated with $S$. aureus 1027 for $72 \mathrm{~h}$ (4 cows, 8 quarter) or $84 \mathrm{~h}$ ( 2 cows, 4 quarter). Somatic cell counts were determined in $12 \mathrm{~h}$ intervals. Based on the development of SCC values, the quarters were classified as fast (3 quarter, filled circles) or slow responding (filled squares). Numbers of quarters from which bacteria could be re-isolated at the indicated time points are given below the graph.

and reveal manifestation of mastitis. Thus, the $S$. aureus infections were conducted in four different trials. Two trials were short term inoculations, spanning an observation period of $24 \mathrm{~h}$. In each of these trials two by two cows were arbitrarily assigned to become inoculated with $E$. coli or $S$. aureus. In other two trials observed over longer periods ( $72 \mathrm{~h}$ or $84 \mathrm{~h}$ ) cows were inoculated with $S$. aureus only.

\subsection{Body temperature, milk yield, differential blood cell numbers}

All cows inoculated with $E$. coli developed fever $\left(>39.2{ }^{\circ} \mathrm{C}\right.$ ) within the first $12 \mathrm{~h}$ after infection with maximal values $\left(40.4{ }^{\circ} \mathrm{C}\right)$ between $12 \mathrm{~h}$ and $18 \mathrm{~h}$ after inoculation (Fig. 3). This was accompanied by a significant leukopenia affecting both neutrophils, lymphoid cells (Fig. 3) and monocytes (data not shown). Leukopenia reached its maximum $18 \mathrm{~h}$ after pathogen inoculation. No increase in body temperature and no changes of blood leukocyte numbers could be seen in S. aureusinoculated animals (Fig. 3) after $24 \mathrm{~h}$.

In animals infected for longer times (72 h-84 h) with $S$. aureus, a slight transient neutropenia could be seen after $48 \mathrm{~h}$ (not significant, data not shown). Milk yield dropped always within the first $12 \mathrm{~h}$ (Fig. 3), but differentially. The milk production almost ceased to only $16 \%$ of initial values in the E. coli-inoculated animals $24 \mathrm{~h}$ after infection. Casein synthesis, indeed, was blunted in the $24 \mathrm{~h}$ inoculated quarters, to less than $5 \%$ of the control quarters [56]. In contrast, milk yield decreased significantly to only about $50 \%$ in S. aureus-inoculated cows $12 \mathrm{~h}$ after pathogen inoculation and stabilized then at around $70 \%$ of the initial yields. Casein synthesis was not impaired in the $S$. aureus inoculated quarters.

\subsection{Bacteriology}

Quarter secretions obtained after pathogen inoculation contained only the pathogens used for infection whereas control quarters 


\section{E. coli}
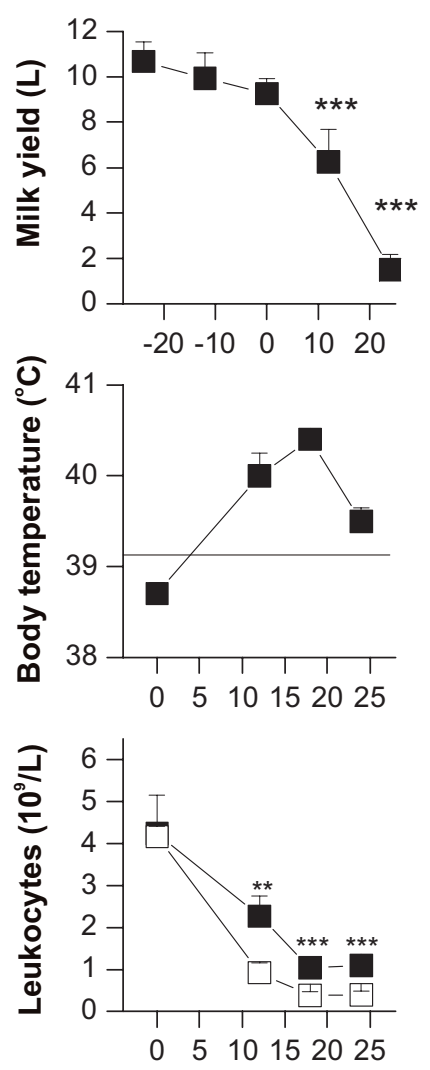

\section{S. aureus}
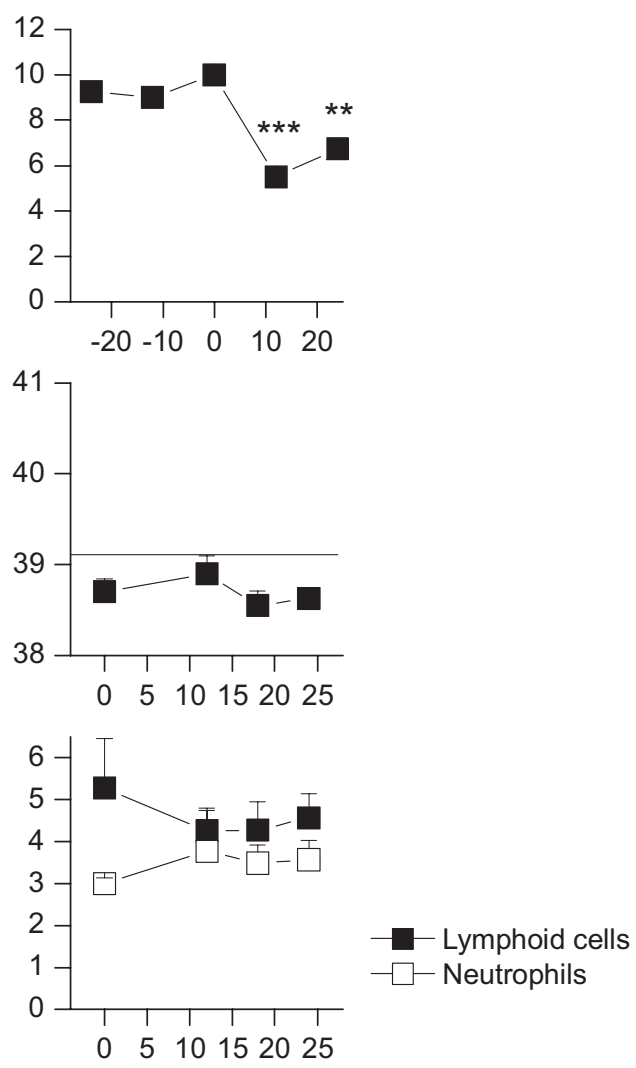

\section{Hours relative to first inoculation}

Figure 3. Milk yield, body temperature, and blood leukocyte counts after experimental inoculation with $S$. aureus or E. coli. Three quarters per animal (4 per group) were sequentially inoculated at $0 \mathrm{~h}, 12 \mathrm{~h}$, and $18 \mathrm{~h}$. Milk yield (means of total milk yield \pm SEM), body temperature (means \pm SEM), and blood leukocyte counts (means \pm SEM) were measured before and after experimental inoculation. $* * P<0.01$; $* * * P<0.001$.

remained bacteriologically negative during the observation period (Tab. II). The infection strains and the reisolated strains of E. coli- and $S$. aureus-inoculated animals showed identical plasmid pattern (data not shown, analyzed by Prof. S. Schwarz, FAL, Mariensee, Germany). In quarters of $E$. coli-inoculated animals which were infected at T0 and T12, a high-grade content of $E$. coli could be determined $12 \mathrm{~h}$ after infection, whereas quarters infected for $6 \mathrm{~h}$ contained fewer bacteria (Tab. II). Numbers of reisolated bacteria from $S$. aureus-inoculated quarters were heterogeneous among the animals. While early after inoculation $(<24 \mathrm{~h})$ we only could reisolate $S$. aureus pathogens from $\sim 60 \%$ of the inoculated udder quarters (Tab. II), this percentage increased with time. However, extending the duration of the observation of $S$. aureus-inoculated animals allowed to consistently reisolate the bacteria from most of the inoculated quarters (Fig. 2). Indeed all four evaluated quarters from two cows having been inoculated for $84 \mathrm{~h}$ were eventually $S$. $a u$ reus-positive (Fig. 2). 
Table II. Reisolation of E. coli and S. aureus from milk secretions after experimental inoculation.

\begin{tabular}{|c|c|c|c|c|c|c|c|c|c|}
\hline \multirow{2}{*}{$\begin{array}{l}\text { Hours of inoculation } \\
\text { of individual quarters }\end{array}$} & \multirow{2}{*}{$\begin{array}{l}\text { Hours after } \\
\text { inoculation }^{2}\end{array}$} & \multicolumn{4}{|c|}{ E. coli-inoculated animals } & \multicolumn{4}{|c|}{ S. aureus- inoculated animals } \\
\hline & & 1054 & 1055 & 1161 & 1162 & 1056 & 1057 & 1159 & 1160 \\
\hline \multirow[t]{3}{*}{$\overline{6 h}$} & -18 & - & - & - & - & - & - & - & - \\
\hline & -6 & - & - & - & - & - & - & - & - \\
\hline & 6 & ++ & + & +++ & + & ++ & + & +++ & + \\
\hline \multirow[t]{3}{*}{$12 \mathrm{~h}$} & -12 & - & - & - & - & - & - & - & - \\
\hline & 0 & - & - & - & - & - & - & - & - \\
\hline & 12 & +++ & +++ & +++ & ++ & +++ & - & ++ & - \\
\hline \multirow[t]{3}{*}{$24 \mathrm{~h}$} & 0 & - & - & - & - & - & - & - & - \\
\hline & 12 & +++ & +++ & +++ & +++ & ++ & + & - & - \\
\hline & 24 & +++ & +++ & +++ & +++ & +++ & + & - & + \\
\hline
\end{tabular}

${ }^{1}$ Quarters of individuals were consecutively inoculated for $24 \mathrm{~h}, 12 \mathrm{~h}$, and $6 \mathrm{~h}$ before culling at $24 \mathrm{~h}$ after the first inoculation.

${ }^{2}$ During the $24 \mathrm{~h}$ period, milk samples were taken before (negative values) and after inoculation (positive values) of individual quarters.

Semiquantitative results of foremilk samples; +: low grade $(0-20 \mathrm{CFU} / 10 \mu \mathrm{L}$ milk); ++: middle grade (21$200 \mathrm{CFU} / 10 \mu \mathrm{L}$ milk); +++: high grade (> $200 \mathrm{CFU} / 10 \mu \mathrm{L}$ milk). Control quarters without inoculated bacteria remained negative with only one quarter of animal 1054 at $24 \mathrm{~h}$ after the first inoculation (low grade positive, data not shown).

Table III. Clinical signs during experimental inoculation with E. coli or S. aureus.

\begin{tabular}{|c|c|c|c|c|c|c|c|c|}
\hline \multirow[t]{2}{*}{ Parameter } & \multicolumn{4}{|c|}{ E. coli- inoculated animals } & \multicolumn{4}{|c|}{ S. aureus- inoculated animals } \\
\hline & 1054 & 1055 & 1161 & 1162 & 1056 & 1057 & 1159 & 1160 \\
\hline$\overline{\text { Body temperature }}$ & 1 & 1 & 2 & 1 & 0 & 0 & 1 & 0 \\
\hline Udder secretion & 3 & 3 & 3 & 3 & 1 & 0 & 0 & 0 \\
\hline Udder palpation & 3 & 3 & 3 & 3 & 1 & 0 & 0 & 1 \\
\hline Milk yield & 3 & 2 & 2 & 3 & 2 & 1 & 2 & 2 \\
\hline General condition & 1 & 1 & 1 & 1 & 0 & 0 & 0 & 0 \\
\hline Clinical score & 11 & 10 & 11 & 10 & 4 & 1 & 3 & 3 \\
\hline Mean $\pm s$ & \multicolumn{4}{|c|}{$10.8 \pm 0.5$} & \multicolumn{4}{|c|}{$2.8 \pm 1.3$} \\
\hline
\end{tabular}

Each parameter was graded on a scale from 0 (no change) to 3 (high grade change). The clinical score is the sum of all parameter scores (0-3: no clinical changes; 4-7: low grade clinical changes; 8-11: middle grade clinical changes; 12-15: high grade clinical changes).

\subsection{Clinical score}

The development of clinical signs during the first $24 \mathrm{~h}$ after inoculation is documented in Table III. E. coli-infected animals showed mainly high-grade changes in udder secretions as well as a high grade inflammatory swelling of the infected udder quarters resulting in a mean clinical score of $10.8 \pm 0.5$. S. aureusinoculated animals showed less clinical signs and especially no signs of udder inflammation (clinical score: $2.8 \pm 1.3$, Tab. III).

\subsection{Pathogen-specific effect upon somatic cell recruitment into milk}

\subsubsection{Quantitative aspects}

The different pathogens exerted a differential effect upon cell recruitment after pathogen inoculation. E. coli caused in the quarters inoculated at T0 a massive and significant rise of SCC already $12 \mathrm{~h}$ after pathogen inoculation (Fig. 1, T0, from 8000 to 1 Mio cells $/ \mathrm{mL}$ ). Interestingly, quarters infected at T12 did not respond with a significant rise in SCC $12 \mathrm{~h}$ 
A) Front right quarter

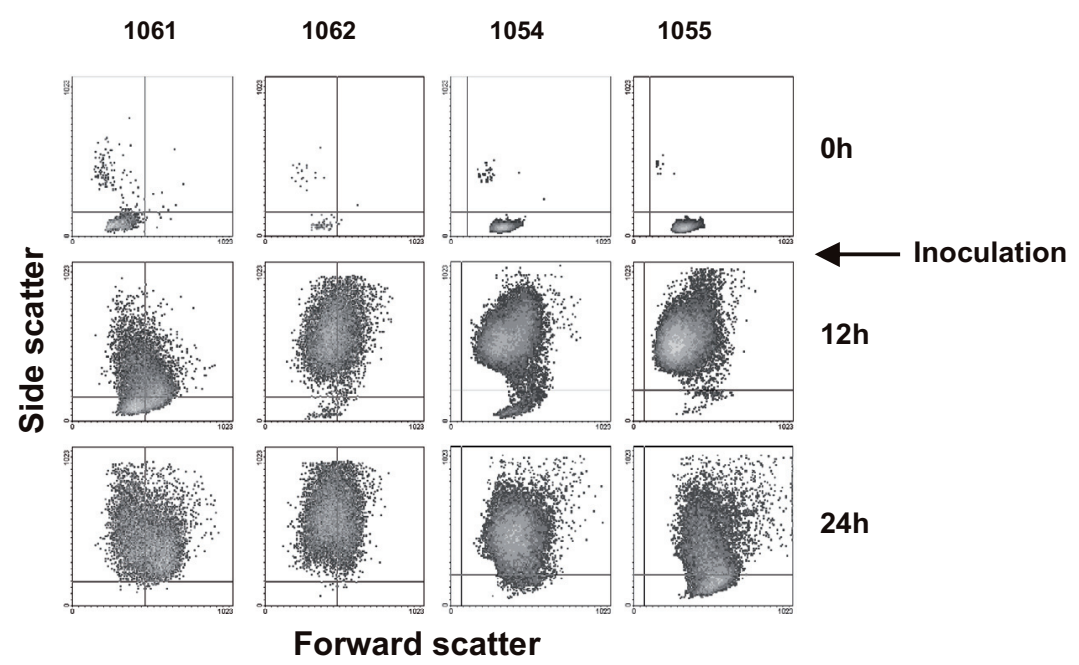

B) Hind right quarter

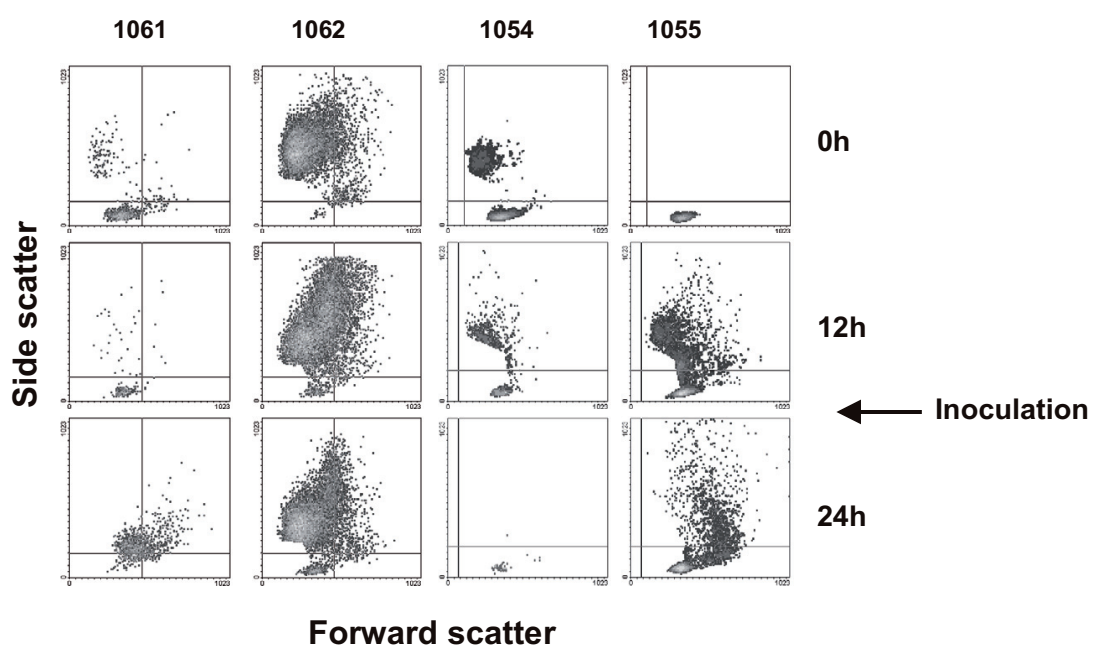

Figure 4. Flow cytometric analysis of milk cells from E. coli -inoculated udder quarters. The animal number is noted on top of the columns. Shown are density plots (forward vs side scatter) of cells after gating on nucleated (acridin orange-positive) and viable (propidium iodide-negative) milk cells. (A) Front right quarter inoculated for $24 \mathrm{~h}$; (B) Hind right quarter inoculated at T12 for $12 \mathrm{~h}$.

later (Fig. 1) and also their relative cellular composition remained unchanged (Fig. 4B, compare second with third row of dotplots).

S. aureus-inoculation caused quantitatively a different pattern of increase in milk cell numbers. In our first two $S$. aureus infection trials, we recorded the changes over $24 \mathrm{~h}$ only. The cell numbers increased significantly within $12 \mathrm{~h}$ after the first infection in all quarters by about $\sim 8$ fold and, remarkably, also in the control quarters. However, subsequently further increased SCC values differed only insignificantly from the $12 \mathrm{~h}$ values (Fig. 1). The increased SCC values in pathogen inoculated 
Table IV. Pathological and histological characterization of udder tissues after experimental inoculation with E. coli or $S$. aureus.

\begin{tabular}{|c|c|c|c|c|c|c|}
\hline & \multicolumn{2}{|c|}{ Acute purulent processes } & \multicolumn{2}{|c|}{ Lymphocytic interstitial processes } & \multicolumn{2}{|c|}{ Interstitial edema } \\
\hline & E. coli & S. aureus & E. coli & S. aureus & E. coli & S. aureus \\
\hline Control quarter & 0.0 & 0.3 & 0.3 & 0.8 & 0.0 & 0.0 \\
\hline $6 \mathrm{~h}$ inoculation & 0.0 & 1.0 & 0.5 & 1.0 & 0.0 & 0.0 \\
\hline $12 \mathrm{~h}$ inoculation & 0.5 & 0.5 & 0.8 & 1.1 & 0.3 & 0.0 \\
\hline $24 \mathrm{~h}$ inoculation & 2.6 & 1.0 & 0.0 & 0.8 & 1.9 & 0.8 \\
\hline
\end{tabular}

Table V. Pathological and histological characterization of lymph nodes after experimental inoculation with E. coli or $S$. aureus.

\begin{tabular}{lccccc}
\hline & \multicolumn{2}{c}{ Follicular hyperplasia } & & \multicolumn{2}{c}{ Acute purulent lymphadenitis } \\
\cline { 2 - 3 } & E. coli & S. aureus & & E. coli & S. aureus \\
\hline Right udder $^{1}$ & 1.0 & 2.5 & & 3.0 & 0.3 \\
Left udder & 1.8 & 2.4 & & 1.3 & 0.0 \\
Right superficial cervical & 2.6 & 2.0 & & 0.0 & 0.0 \\
Left superficial cervical & 2.1 & 2.3 & & 0.0 & 0.0 \\
\hline
\end{tabular}

${ }^{1}$ The right udder lymph node drained the quarter which was inoculated for $12 \mathrm{~h}$ or $24 \mathrm{~h}$; the left udder lymph node drained the side of the control quarter and the quarter which was inoculated for $6 \mathrm{~h}$. Values are presented of means ( $n=4$ cows per group) of scores from 0 (absent) to 3 (high grade).

quarters were statistically not different from control quarters $(p>0.1)$. The quarters of cows inoculated with $S$. aureus for $72 \mathrm{~h}$ or $84 \mathrm{~h}$ were either fast (three quarter) or slow (nine quarter) responding with elevated SCC values (Fig. 2).

\subsubsection{Qualitative aspects}

Flow cytometric analysis showed that all animals started with milk containing very few neutrophils, and a significant population of cells with lymphoid morphology (shown for E. coli-inoculated animals in Fig. 4A, first row of dotplots). However, different quarters of the same individual eventually differed vastly in the content of somatic cells (Fig. 4, compare animal 1062 at time 0 ).

This was mainly caused by immigrating cells with morphological characteristics of neutrophils (Fig. 4A, compare second with third row of dotplots). S. aureus expositions for $24 \mathrm{~h}$, on the contrary, neither influenced the total cell number (Fig. 1, S. aureus) nor the relative proportions of the various cell types found in the milk (not shown). Taken together, the data show that both pathogens exert a profoundly different, pathogen-specific effect upon the inoculation-caused recruitment of cells.

\section{6. $E$. coli inoculation caused clear mastitis pathology}

Acute purulent processes dominated in udder tissues inoculated with $E$. coli for $24 \mathrm{~h}$ (Tab. IV), but also interstitial edemas were seen, especially in $24 \mathrm{~h}$ - inoculated quarters. Lymphocytic interstitial processes were only infrequently seen. Tissues of individual $S$. $a u$ reus-inoculated animals showed some signs of acute purulent processes, however with no apparent correlation to the duration of the infection per quarter (Tab. IV). All lymph nodes examined (regional udder lymph nodes and distant control lymph nodes) showed signs of follicular hyperplasia both in E. coli- and $S$. aureus-inoculated animals, but only udder lymph nodes draining the $24 \mathrm{~h}$ and $12 \mathrm{~h}$ inoculated quarters in E. coli-inoculated animals, showed an acute purulent lymphadenitis (Tab. V). In summary, E. coli inoculation resulted in a much more severe pathology than caused by $S$. aureus. 
Table VI. Absolute copy numbers of defensins (universal defensins (uDEF))-, BNBD5-, and TLR-mRNA in udder tissues of mock-inoculated quarters.

\begin{tabular}{lcccccc}
\hline & BNBD5 & uDEF & TLR2 & TLR3 & TLR4 & TLR6 \\
\hline Mean & 189 & 11921 & 4894 & 242 & 7776 & 1623 \\
SEM & 58 & 5985 & 1013 & 67 & 1713 & 451 \\
CV & 30.7 & 50.2 & 20.7 & 27.5 & 22.0 & 27.8 \\
$n$ & 8 & 8 & 8 & 8 & 8 & 8 \\
\hline
\end{tabular}
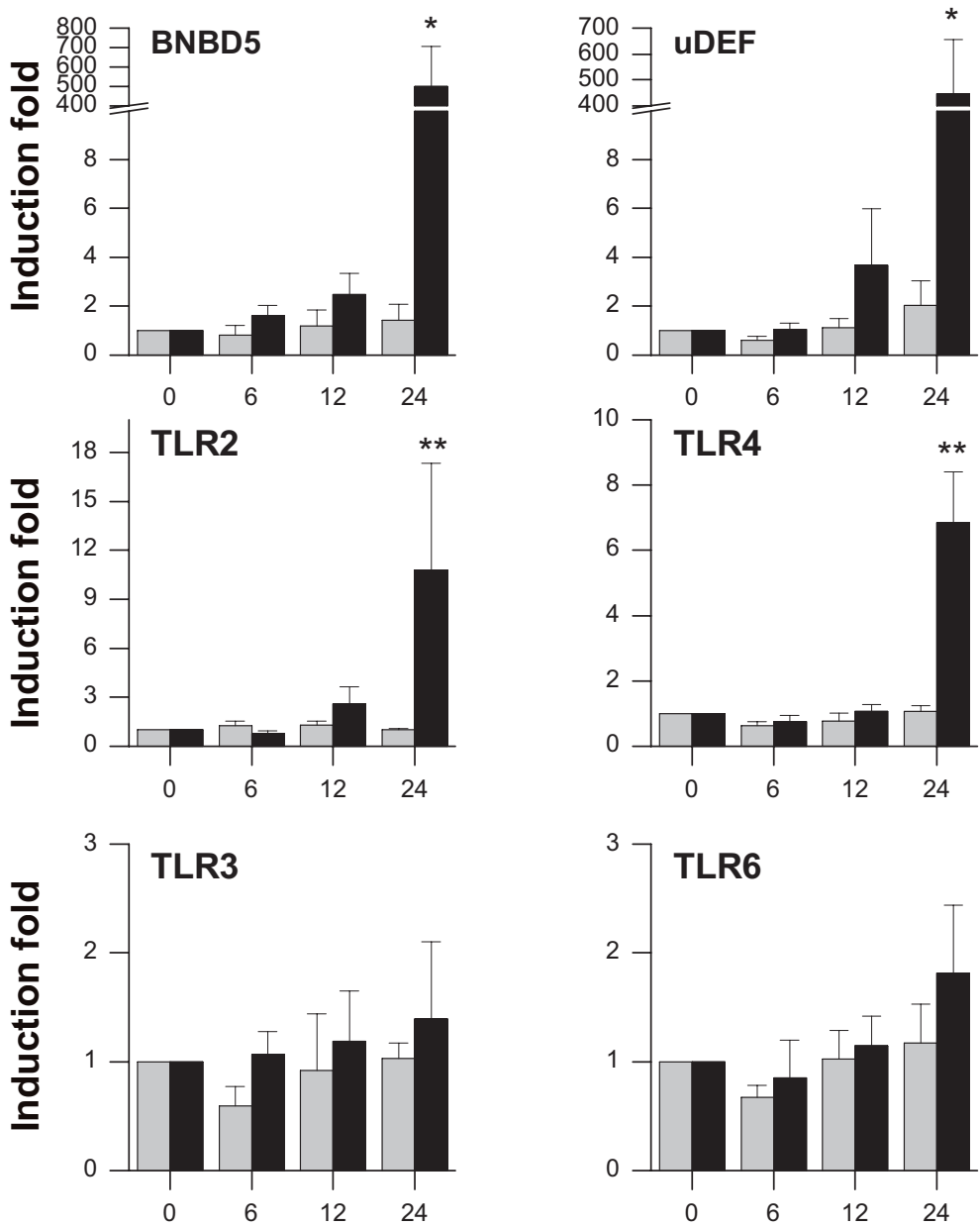

\section{Hours after inoculation}

\section{S. aureus}

E. coli

Figure 5. Expression of TLR and $\beta$-defensin genes in udder tissues after experimental inoculation with S. aureus or E. coli. mRNA for the indicated TLRs, BNBD5, and $\beta$-defensins (uDEF) was quantified in tissue samples of udder quarters inoculated for $24 \mathrm{~h}, 12 \mathrm{~h}$ and $6 \mathrm{~h}$. The expression levels of the genes were calculated as $\mathrm{x}$-fold induction compared to the expression level in the control quarters (bars time $0 \mathrm{~h}=1$ ) $(n=4$ per quarter, means $\pm \mathrm{SEM}) . * P<0.05 ; * * P<0.01$. 


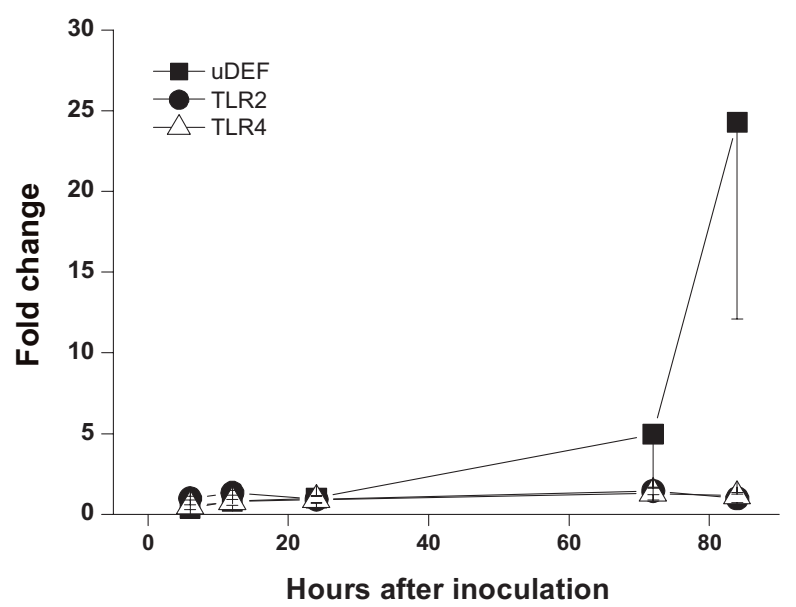

Figure 6. $\beta$-defensin and TLR copies following intramammary inoculation with $S$. aureus. mRNA for TLR2, TLR4, and $\beta$-defensins (universal defensin (uDEF)) was quantified in tissue samples of udder quarters inoculated for $12 \mathrm{~h}$ ( 4 quarters), $24 \mathrm{~h}$ (4 quarters), $72 \mathrm{~h}$ (8 quarters), and $84 \mathrm{~h}$ (6 quarters). The expression levels of the genes (means \pm SEM) were calculated as $x$-fold induction compared to the expression level in the control quarters (averaged mRNA copies of control quarters were set as 1 ). The $84 \mathrm{~h}$ values of uDEF are statistically significant different from the controls $(*, p<0.05)$.

\section{7. $E$. coli inoculation, but not $S$. aureus increased TLR2, TLR4, and $\beta$-defensin expression in udder tissues within $24 \mathrm{~h}$ after pathogen inoculation}

The absolute mRNA copy numbers, as measured in the uninoculated control quarters are given in Table VI. The variance was very high for both $\beta$-defensin parameters, due to one of four $E$. coli-inoculated cows and one of the eight $S$. aureus-inoculated cows.

E. coli-inoculation caused a significant $(p<0.001)$ and massive upregulation of TLR2 and TLR4 expression $24 \mathrm{~h}$ after inoculation, compared to the uninoculated control quarters (Fig. 5). The expression remained low in all control quarters, at values typical for healthy, uninoculated animals. Similarly, BNBD5, as well as the other $\beta$-defensinencoding genes described as 'universal defensin' (uDEF), were dramatically upregulated (> 400 fold) in udder quarters E. coliinoculated for $24 \mathrm{~h}$, but remained low in the control quarters. The level of significance is lower here $(p<0.05)$, due to the large variation. The mean expression levels of the other TLR receptors remained almost unchanged, and small changes were all statistically in- significant. In no case occurred a significant down-regulation of either TLR gene expression or defensin gene expression compared to control quarters.

S. aureus inoculations, in contrast, did not significantly modulate the expression of any of these genes within $24 \mathrm{~h}$ after exposition (Fig. 5). Hence, it was necessary to run additional inoculation trials, to eventually verify that this $S$. aureus strain is indeed capable at all to elicit an immune response in mammary tissue. We found that $\beta$-defensin expression may eventually be strongly upregulated at later times after inoculation with $S$. aureus (Fig. 6). Two from among the six animals infected for longer periods $(72 \mathrm{~h}$ or $84 \mathrm{~h})$ revealed in one quarter only a doubled $\beta$-defensin mRNA concentration, while the other pathogen inoculated quarter did not react. The other four animals revealed 5-500 fold increased $\beta$-defensin copy numbers, in at least one quarter. This large quarter and animal individual influence precludes a meaningful statistical analysis of these data. Regarding the expression of TLRencoding genes, we found that inoculation with $S$. aureus, unlike with $E$. coli, do not regulate the expression of any of these genes 
Control

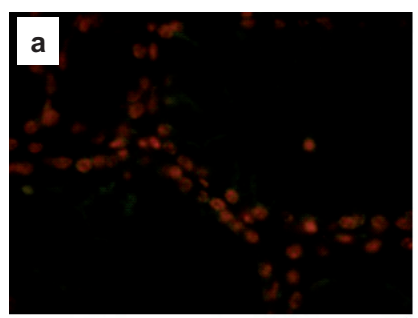

w/o $A B$
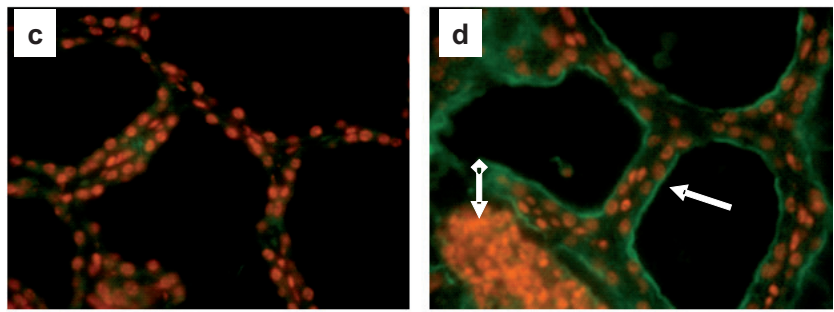

$\alpha$ TLR2
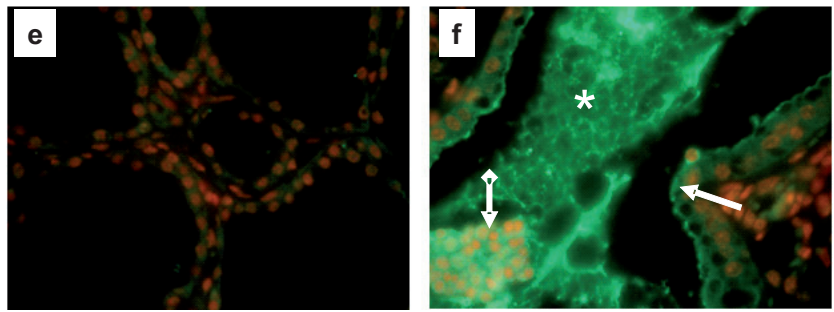

$\alpha \mathrm{LAP}$

\section{4h inoculated}

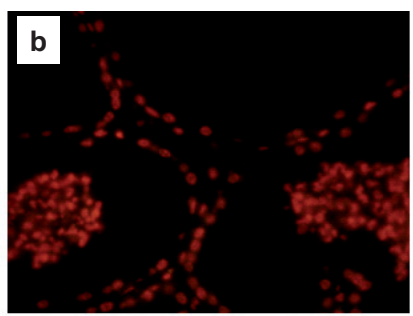
AB 


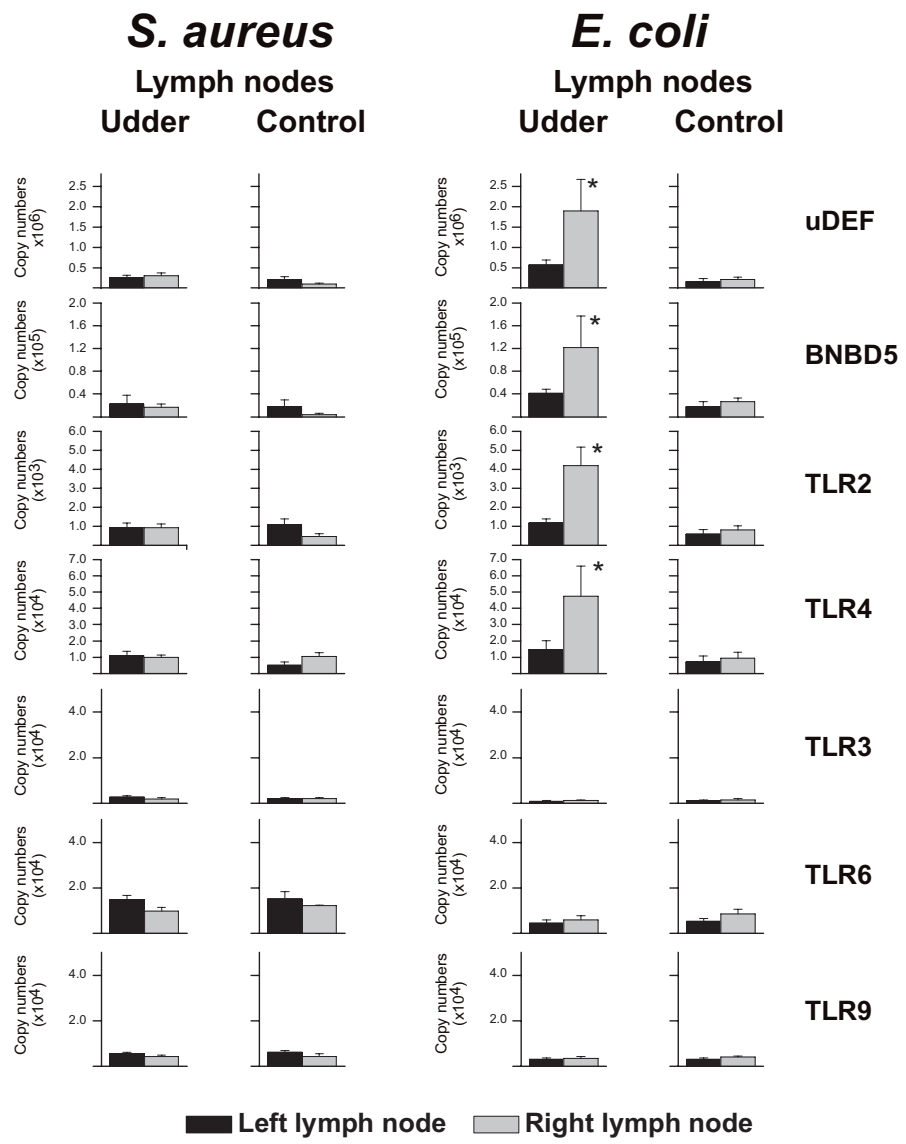

Figure 8. TLR and $\beta$-defensin expression in regional udder lymph nodes and peripheral lymph nodes $24 \mathrm{~h}$ after experimental inoculation with E. coli or S. aureus. The left udder lymph nodes drained the control quarter and the $6 \mathrm{~h}$ inoculated quarter; the right udder lymph node drained quarters inoculated for $12 \mathrm{~h}$ and $24 \mathrm{~h}$. Control lymph nodes refer to left and right peripheral lymph nodes. Means \pm SEM of mRNA copy numbers. $* P<0.05$.

isk), in sections from $E$. coli-inoculated udder quarters after $24 \mathrm{~h}$. This staining appears to be specific, since in serial sections used for immune histochemistry the TLR2 specific antibody never stained these clumps of precipitated milk. These results prove for TLR2 and LAP that increased mRNA abundance of these factors results in increased protein abundance. It may be added that the poor decoration of immigrating leucocytes with the TLR2 antibody is not a general feature, since positive TLR2 staining of such cells was frequently seen in other experiments, using in freeze-cut sections from infected udders (not shown).

\subsection{TLR and defensin expression in lymph nodes}

TLR- and $\beta$-defensin expression was examined in local mammary lymph nodes and peripheral lymph nodes (superficial cervical lymph nodes). In E. coli-inoculated animals, the right mammary lymph nodes draining the quarters inoculated for $24 \mathrm{~h}$ and $12 \mathrm{~h}$ featured significantly increased TLR2 and TLR4 expression. In contrast, the left mammary lymph node, draining the control quarter and the quarter inoculated for only $6 \mathrm{~h}$, showed no such modulated expression (Fig. 8). The 
same pattern was seen for UDEF and BNBD5 mRNA which were significantly upregulated in the right mammary lymph nodes of E. coliinoculated animals. Control lymph nodes in the periphery showed no modulated expression of either TLR or defensin genes. S. aureus inoculation did not cause any infection-related change in the expression of these genes, in none of the lymph node analyzed.

\section{DISCUSSION}

We previously described the jointly upregulated expression of pattern recognition receptor genes TLR2 and TLR4 as well as the enhanced expression of the $\beta$-defensin gene BNBD5 in naturally occurring clinical cases of $S$. aureus and E. coli-mastitis, based on samples collected in a field study [13]. Hence, those samples were derived from animals in different, uncontrolled stages of lactation, and uncontrolled durations of infections.

Controlled, experimental infections of the udder were performed during the last 30 years to study various aspects of host-pathogen interactions. These previous studies focused generally on changes of milk composition during the course of an induced mastitis, the time course of effector-cell appearance in the milk, their functional capabilities, and the expression of soluble immune mediators $[3,12,41,43]$.

Here, we addressed the sequence of events occurring during the first $24 \mathrm{~h}$ after inoculation. We established an experimental model system based on animals of the same age and stage of lactation to insure comparable physiological situations in the host. We used asseverated strains of pathogens to provide comparable conditions regarding the pathogens. We analyzed the early events after host-pathogen contact, since conceivably these are decisive for the subsequent pathogenesis of mastitis in cattle. It is known since long that $E$. coli pathogens are prone to result in acute infections and inflammations of the udder, while S. aureus pathogens very frequently cause subclinical, chronic infections, but the molecular mechanisms underpinning this difference are largely unknown.
The bacteria strains used in our study were not characterized in depth regarding their virulence factors, so far. However, they are relevant since they were isolated from cows suffering from cases of clinical mastitis. We verified in pilot trials that $500 \mathrm{CFU}$ of the $E$. coli strain consistently cause acute mastitis within $12 \mathrm{~h}$, while $10000 \mathrm{CFU}$ of the $S$. aureus strain reliably causes subclinical mastitis, eventually after longer incubation times ( $>40 \mathrm{~h}$ ). Hence, while our main interest in this study was on the analysis of early stage $(<24 \mathrm{~h})$ of host-pathogen interaction, we include also the results from the long time infection trials 3 and 4 (72 h and $84 \mathrm{~h}$, respectively) verifying that our strain, as used here, establishes subclinical infections, indeed.

Regarding the inoculation doses used, it should be noted that others achieved clinical mastitis with as little as 72-74 CFU/quarter of either bacteria species [3]. However, it is well known that different strains of the same bacterial pathogen species may differ vastly in their genome [20,53]. Indeed, we wanted to establish a model for subclinical mastitis. Such subclinical infections are characterized by very mild or no clinical signs of inflammation, often associated with individual responses. While milk cell counts rose very quickly within the first $12 \mathrm{~h}$ in two cows of trial 3 (Fig. 1), it took almost $60 \mathrm{~h}$ in other cows to react with levels $>1$ Mio cells/mL (Fig. 2). These individual and even udder quarter dependent differential reactions upon inoculations with this strain of $S$. aureus were also reflected in the selective and variable activation of $\beta$-defensin expression (see below). In summary, our isolated $S$. aureus strains seems to represent a quite relevant model for such subclinical infections [34].

Standardization of animals is a major issue in experimental infection models. In addition to a hormonal synchronization we selected animals which never had mastitis before to avoid influences of adaptive immune mechanisms. Although bacteria-specific antibodies in serum or milk were not determined, the proven absence of previous history of mastitis made it unlikely that the animals responded in our model with components (antibodies, 
memory T-cells) of the adaptive immune system. Since high SCC values can ameliorate or alter the course of a natural or experimental infection $[28,45]$, we only inoculated animals having consistently low SCC values $(<100000$ cells $/ \mathrm{mL})$ in their quarter milk. This was monitored over a period of three weeks prior to challenge and assured that the local immune system was not alerted or altered. At the time of inoculation, the leukocyte populations in milk consisted mainly of lymphoid cells with variant numbers of neutrophilic granulocytes (Fig. 4).

The homogeneous responses of E. coliinoculated animals support the assumption of proper standardization. Their clinical symptoms, obvious $24 \mathrm{~h}$ after pathogen inoculation, resulted in similar clinical scores (Tab. III) and are characteristic for an acute inflammatory response. They are in line with observations made by Burvenich et al. [8]. Also, we could re-isolate the same strain of $E$. coli bacteria from inoculated quarters as used for the infections (Tab. II). Our E. coli infections caused a much stronger depletion of white blood cells from the blood stream than what was recorded after LPS infusions into the udder [38].

In contrast, the response to $S$. aureus inoculations was more heterogeneous. All animals lacked any signs of an acute inflammation. The clear proof that $S$. aureus and the host were in contact and exchanged information during the first $24 \mathrm{~h}$ of infection was the significant drop of milk yield (Fig. 3) which, however, was not paralleled by a clear pathogen-induced SCC increase (Fig. 1). Moreover, the highly significant up-regulation of TGF- $\beta$ in control quarter tissues $24 \mathrm{~h}$ after inoculation with $S$. aureus strongly indicates that the animals responded systemically after perceiving the presence of the $S$. aureus pathogens [62].

The infections with this $S$. aureus strain obviously need more than $24 \mathrm{~h}$ to establish. This could be seen from the elevated SCC values and increased $\beta$-defensin copy numbers, as recorded from the $72 \mathrm{~h}$ and $84 \mathrm{~h}$ S. aureuschallenge trials (Figs. 2 and 6).

The individually differing responses of the various host animals to the $10000 \mathrm{CFU}$ $S$. aureus per quarter were also reflected by the heterogeneous numbers of bacteria, which were re-isolated after inoculation (Tab. II). This is basically in line with observations by Schukken et al. [40], who noted that 18 out of $48 \mathrm{~S}$. aureus-infected udder quarters remained bacteriologically negative throughout the study. The poorer qualitative and quantitative recovery of $S$. aureus, compared to E. coli pathogens after infection, conceivably indicates a slower multiplication rate of the $S$. aureus bacteria in the udder, albeit their generation time is similar to the E. coli pathogens under laboratory culture conditions.

E. coli, but not $S$. aureus infections resulted in a consistent and strong recruitment of somatic cells into the milk. The failure of $S$. $a u$ reus to significantly increase the cell counts in milk is surprising, since it was demonstrated that the major molecular patterns of $S$. aureus (LTA) and E. coli (LPS) can induce relevant immune mediators (CXCL8, TNF- $\alpha$, IL-1 $\beta$ ) after in vitro stimulation of primary MEC. However, the effect of LTA including the induction of the neutrophil-attractive chemokine CXCL8 was only transient [48].

This response, however, was not observed during the first $24 \mathrm{~h}$ after $S$. aureus inoculation in our model. In part, this is in line with findings of Bannerman et al. [3], who recognized in vivo significant less induction of CXCL8, C5a, and TNF- $\alpha$ by S. aureus, as compared to $E$. coli. The reduced induction of some pro-inflammatory cytokines may also explain why $S$. aureus-inoculated animals showed no signs of fever and leukopenia compared to E. coli-inoculated animals (Fig. 3). The lack of response towards $S$. aureus is unclear. It may reside in a differential presence of humoral milk factors which may alter the ability of bacteria to attach to MEC $[1,16]$, or to survive intracellular in macrophages [15] or epithelial cells [25].

TLR2, TLR4, as well as $\beta$-defensins were significantly upregulated $24 \mathrm{~h}$ after inoculation of udder quarters with $E$. coli, selectively in udder tissue and in local udder lymph nodes. Other TLRs (TLR3, TLR6, and TLR9) remained unaffected during this period (Figs. 5 and 8). These results show that the expression of TLR2 and TLR4 receptors is dynamically 
regulated during infection, while the expression of TLR3 and TLR6 is only marginally influenced by ongoing mastitis. They also show that changes in the expression profiles of the udder quarters are spatially regulated and restricted to the infected quarter. They are correlated with the duration of pathogen presence within the quarter, not within the animal. Hence, the regulation of the expression of these genes is largely independent from systemic factors but rather controlled by factors inside the infected udder quarter.

These results are basically in line with our previous observations from cases of clinical mastitis where we recognized an upregulated expression of TLR2 and TLR4 but not of TLR9 [13]. However, whereas mastitis related $\beta$-defensins showed a 10-30 fold increase in long time infected udders from a field study [13], the experimental infection resulted in a much higher increase (about 500 fold, Fig. 5). This indicates that to date unidentified counter-regulatory mechanisms may be responsible for the less enhanced expression of these molecules in long-term infected udders.

We could also unequivocally demonstrate by immunohistology that MEC are the major cell type expressing both $\beta$-defensins and TLRs (Fig. 7). Regarding TLR2, these images prove first time, to the best of our knowledge, that this factor indeed is localized in the apical membrane of the MEC, which could only be assumed so far. Similarly, we show that the distribution of the LAP-peptide is polarized towards the apical membrane of the MEC. This, together with fact that this antibody stained heavily the milk of infected quarters only, proves for the cow that LAP serves as a secreted bactericidal peptide in milk. This had previously been concluded on the basis of MEC restricted localization of the LAP- [50] and BNBD5-mRNA [13]. The concentrations of $\beta$-defensins in milk have so far only been reported from women, amounting up to $40 \mu \mathrm{g} / \mathrm{mL}[2,19]$.

The inflammatory PMN in the histological sections were considerably less stained and thus are unlikely to contribute to the strong TLR2 (and most likely also TLR4) RNA mes- sage which could be measured $24 \mathrm{~h}$ after E. coli inoculation.

The lack of TLR3, TLR6, and TLR9 modulation indicates that the expression of these PRRs is not regulated upon ligand binding. Their expression was also unchanged by the infection in local mammary lymph nodes as well as in udder-distant lymph nodes after experimental inoculation with E. coli or $S$. $a u$ reus (Fig. 8), albeit these immune cell rich tissues contain TLR9 expressing cell types, such as dendritic cells $[9,21]$.

The molecular controls determining an upregulation of TLR2, TLR4, and $\beta$-defensin expression are unknown. They may be associated with elevated levels of pro-inflammatory cytokines, since it occurred only in the E. coli-inoculated animals, which concomitantly showed cytokine-induced fever. Expression levels of TLR3, 6, and 9, on the contrary, remained unchanged, indicating that their expression is regulated differently from that of the former group of TLRs.

$S$. aureus-inoculated animals showed unchanged expression levels of all TLRs and $\beta$-defensin genes during the first $24 \mathrm{~h}$ after pathogen inoculation (Fig. 5). We recorded no signs of inflammation in these animals during the first $24 \mathrm{~h}$ of pathogen exposure. They developed no fever and did not reveal elevated SCC values. Hence, the S. aureusinduced mechanisms causing the consistent and statistically significant drop in milk yield are independent from immune mechanisms. It is unclear, why the host animals do not respond with a visible pro-inflammatory reaction early after $S$. aureus-inoculations. This may in part be specific for the particular $S$. $a u$ reus strain used for challenge, since others demonstrated a rise in SCC values within $24 \mathrm{~h}$ after a $S$. aureus challenge [3]. Striking differences between $S$. aureus- and E. colielicited gene expressions showed up when we analyzed mammary tissue samples at later stages of pathogen exposure $(72 \mathrm{~h}$ to $84 \mathrm{~h}$, $S$. aureus only). Here, only $\beta$-defensin genes were upregulated whereas TLR2 and TLR4 mRNA remained at the level of not inoculated quarters (Fig. 6). Although we could not compare E. coli-elicited responses at such stages, 
this clearly points to bacterial species-specific modes of interactions with the host, and represents a correlate of different courses of the disease (clinical or subclinical).

TLR2 and TLR4 upregulation in the udder occurred much later than the rise in SSC numbers, fever, and drop in milk yield, parameters which changed already $\sim 12 \mathrm{~h}$ earlier. Thus, expression modulation of PRRs and also the de novo synthesis of defense molecules are rather late events during the early phase of an infection. However, the time kinetic experiments using sequentially infected pathogen inoculated udder quarters must be interpreted with some care since the cellular response within $12 \mathrm{~h}$ of quarters inoculated at T12 was not comparable to those infected at T0 (Fig. 4). This indicates that the response in subsequently inoculated quarters is affected by systemic effects (e.g. cytokines, lipid mediators, neuromediators) induced in previously challenged quarters. This resembles somehow the findings of Shuster and Harmon [44], who noted that endotoxin infusion into udders quarters induced an acute response with systemic involvement, whereas subsequent infusions into the same quarters failed to induce systemic responses. They also noted a persistent mammary leukocytosis in repeatedly infused quarters. This could indicate that the systemic response in E. coliinoculated animals results in a refractory state of the tissues, e.g. adjacent, not-inoculated quarters. An endotoxin-mediated desensitization of monocytes-macrophages resulting in a decreased production of pro-inflammatory cytokines after re-exposure to endotoxin has recently been validated in vitro [46].

Leukopenia and fever are usually attributed to the E. coli endotoxin LPS [18] which induces high levels of TNF- $\alpha$ within $8-16 \mathrm{~h}$ after infection $[3,17]$. The pro-apoptotic effect of TNF- $\alpha$ for lymphocytes and neutrophils [29, $36,51]$ may explain the leukopenia in our model. In contrast, the upregulation of TLR2, TLR4, and $\beta$-defensins occurs spatially restricted, in specific udder quarters, and hence are independent from systemic, circulating TNF- $\alpha$ and other inflammatory cytokines. Although it has been shown that IFN- $\gamma$ and
TNF- $\alpha$ cause enhanced expression of TLR2 and TLR4 on renal epithelial cells during inflammation [60], we recognized upregulation only locally in udder tissue and regional lymph nodes (Figs. 5 and 8) but not in peripheral control lymph nodes (Fig. 8). Thus it is more likely that modulated expression of $\beta$-defensins and TLRs results from locally induced soluble mediators and signaling through baseline expressed PRRs [57, 58]. This might also explain why the systemic, cytokine-mediated effects leading to an altered responsiveness of adjacent quarters did not result in an upregulation of TLRs and $\beta$-defensins.

Whether an enhanced expression of TLRs following infection is beneficial for the animal (better recognition of bacteria) as stated by Hayashi et al. [14] or whether it results in a too strong and deleterious inflammatory response needs further investigations.

Acknowledgements. We are grateful for the technical assistance of Angelika Deike, Bärbel Pletz, and Marlies Deutscher (sequencing). This work was supported by grants from the Deutsche Forschungsgemeinschaft (FOR 585). The European Community through EADGENE Network of Excellence also supported this work.

\section{REFERENCES}

[1] Almeida R.A., Matthews K.R., Cifrian E., Guidry A.J., Oliver S.P., Staphylococcus aureus invasion of bovine mammary epithelial cells, J. Dairy Sci. (1996) 79: 1021-1026.

[2] Armogida S.A., Yannaras N.M., Melton A.L., Srivastava M.D., Identification and quantification of innate immune system mediators in human breast milk, Allergy Asthma Proc. (2004) 25:297-304.

[3] Bannerman D.D., Paape M.J., Lee J.W., Zhao X., Hope J.C., Rainard P., Escherichia coli and Staphylococcus aureus elicit differential innate immune responses following intramammary infection, Clin. Diagn. Lab. Immunol. (2004) 11:463-472.

[4] Barkema H.W., Schukken Y.H., Lam T.J., Beiboer M.L., Wilmink H., Benedictus G., Brand A., Incidence of clinical mastitis in dairy herds grouped in three categories by bulk milk somatic cell counts, J. Dairy Sci. (1998) 81:411-419.

[5] Birchler T., Seibl R., Buchner K., Loeliger S., Seger R., Hossle J.P., Aguzzi A., Lauener R.P., Human toll-like receptor 2 mediates induction of the antimicrobial peptide human beta-defensin 2 in response to bacterial lipoprotein, Eur. J. Immunol. (2001) 31:3131-3137. 
[6] Boman H.G., Peptide antibiotics and their role in innate immunity, Annu. Rev. Immunol. (1995) 13:61-92.

[7] Burkhardt F., Mikrobiologische Diagnostik, Georg Thieme, Stuttgart, Germany, 1992.

[8] Burvenich C., Van Merris V., Mehrzad J., DiezFraile A., Duchateau L., Severity of E. coli mastitis is mainly determined by cow factors, Vet. Res. (2003) 34:521-564.

[9] Chuang T.H., Ulevitch R.J., Cloning and characterization of a sub-family of human toll-like receptors: hTLR7, hTLR8 and hTLR9, Eur. Cytokine Netw. (2000) 11:372-378.

[10] Diamond G., Kaiser V., Rhodes J., Russell J.P., Bevins C.L., Transcriptional regulation of betadefensin gene expression in tracheal epithelial cells, Infect. Immun. (2000) 68:113-119.

[11] Diamond G., Russell J.P., Bevins C.L., Inducible expression of an antibiotic peptide gene in lipopolysaccharide-challenged tracheal epithelial cells, Proc. Natl Acad. Sci. USA (1996) 93:51565160 .

[12] Ebling T.L., Fox L.K., Bayles K.W., Bohach G.A., Byrne K.M., Davis W.C., Ferens W.A., Hillers J.K., Bovine mammary immune response to an experimental intramammary infection with a Staphylococcus aureus strain containing a gene for staphylococcal enterotoxin C1, J. Dairy Sci. (2001) 84:2044-2050.

[13] Goldammer T., Zerbe H., Molenaar A., Schuberth H.J., Brunner R.M., Kata S.R., Seyfert H.M., Mastitis increases mammary mRNA abundance of betadefensin 5, toll-like-receptor 2 (TLR2), and TLR4 but not TLR9 in cattle, Clin. Diagn. Lab. Immunol. (2004) 11:174-185.

[14] Hayashi F., Means T.K., Luster A.D., Toll-like receptors stimulate human neutrophil function, Blood (2003) 102:2660-2669.

[15] Hebert A., Sayasith K., Senechal S., Dubreuil P., Lagace J., Demonstration of intracellular Staphylococcus aureus in bovine mastitis alveolar cells and macrophages isolated from naturally infected cow milk, FEMS Microbiol. Lett. (2000) 193:57-62.

[16] Hensen S.M., Pavicic M.J., Lohuis J.A., Poutrel B., Use of bovine primary mammary epithelial cells for the comparison of adherence and invasion ability of Staphylococcus aureus strains, J. Dairy Sci. (2000) 83:418-429.

[17] Hoeben D., Burvenich C., Trevisi E., Bertoni G., Hamann J., Bruckmaier R.M., Blum J.W., Role of endotoxin and TNF-alpha in the pathogenesis of experimentally induced coliform mastitis in periparturient cows, J. Dairy Res. (2000) 67:503-514.

[18] Jain N.C., Lasmanis J., Leucocytic changes in cows given intravenous injections of Escherichia coli endotoxin, Res. Vet. Sci. (1978) 24:386-387.
[19] Jia H.P., Starner T., Ackermann M., Kirby P., Tack B.F., McCray P.B. Jr, Abundant human beta-defensin1 expression in milk and mammary gland epithelium, J. Pediatr. (2001) 138:109-112.

[20] Jorgensen H.J., Mork T., Caugant D.A., Kearns A., Rorvik L.M., Genetic variation among Staphylococcus aureus strains from Norwegian bulk milk, Appl. Environ. Microbiol. (2005) 71:8352-8361.

[21] Kadowaki N., Ho S., Antonenko S., Malefyt R.W., Kastelein R.A., Bazan F., Liu Y.J., Subsets of human dendritic cell precursors express different toll-like receptors and respond to different microbial antigens, J. Exp. Med. (2001) 194:863-869.

[22] Kaisho T., Akira S., Toll-like receptor function and signaling, J. Allergy Clin. Immunol. (2006) 117:979-987.

[23] Kornalijnslijper E., Beerda B., Daemen I., van der Werf J., van Werven T., Niewold T., Rutten V., Noordhuizen-Stassen E., The effect of milk production level on host resistance of dairy cows, as assessed by the severity of experimental Escherichia coli mastitis, Vet. Res. (2003) 34:721-736.

[24] Kremer W.D., Noordhuizen-Stassen E.N., Grommers F.J., Daemen A.J., Henricks P.A., Brand A., Burvenich C., Preinfection chemotactic response of blood polymorphonuclear leukocytes to predict severity of Escherichia coli mastitis, J. Dairy Sci. (1993) 76:1568-1574.

[25] Lammers A., Nuijten P.J., Smith H.E., The fibronectin binding proteins of Staphylococcus aureus are required for adhesion to and invasion of bovine mammary gland cells, FEMS Microbiol. Lett. (1999) 180:103-109.

[26] Middleton J.R., Luby C.D., Viera L., Tyler J.W., Casteel S., Short communication: influence of Staphylococcus aureus intramammary infection on serum copper, zinc, and iron concentrations, J. Dairy Sci. (2004) 87:976-979.

[27] Miller G.Y., Bartlett P.C., Lance S.E., Anderson J., Heider L.E., Costs of clinical mastitis and mastitis prevention in dairy herds, J. Am. Vet. Med. Assoc. (1993) 202:1230-1236.

[28] Nickerson S.C., Boddie R.L., Owens W.E., Watts J.L., Effects of novel intramammary device models on incidence of mastitis after experimental challenge, J. Dairy Sci. (1990) 73:2774-2784.

[29] Norimatsu M., Ono T., Aoki A., Ohishi K., Tamura Y., In vivo induction of apoptosis in murine lymphocytes by bacterial lipopolysaccharides, J. Med. Microbiol. (1995) 43:251-257.

[30] Paape M.J., Bannerman D.D., Zhao X., Lee J.W., The bovine neutrophil: structure and function in blood and milk, Vet. Res. (2003) 34:597-627.

[31] Pyorala S., Kaartinen L., Kack H., Rainio V., Efficacy of two therapy regimens for treatment of 
experimentally induced Escherichia coli mastitis in cows, J. Dairy Sci. (1994) 77:453-461.

[32] Rainard P., Riollet C., Innate immunity of the bovine mammary gland, Vet. Res. (2006) 37:369-400.

[33] Riollet C., Rainard P., Poutrel B., Differential induction of complement fragment C5a and inflammatory cytokines during intramammary infections with Escherichia coli and Staphylococcus aureus, Clin. Diagn. Lab. Immunol. (2000) 7:161-167.

[34] Riollet C., Rainard P., Poutrel B., Cell subpopulations and cytokine expression in cow milk in response to chronic Staphylococcus aureus infection, J. Dairy Sci. (2001) 84:1077-1084.

[35] Roosen S., Exner K., Paul S., Schroder J.M., Kalm E., Looft C., Bovine beta-defensins: identification and characterization of novel bovine beta-defensin genes and their expression in mammary gland tissue, Mamm. Genome (2004) 15:834-842.

[36] Sanchez-Cordon P.J., Nunez A., Salguero F.J., Pedrera M., Fernandez de Marco M., GomezVillamandos J.C., Lymphocyte apoptosis and thrombocytopenia in spleen during classical swine fever: role of macrophages and cytokines, Vet. Pathol. (2005) 42:477-488.

[37] Schmidt Madsen P., Fluoro-opto-electronic cell counting on milk, J. Dairy Res. (1975) 42:227-239.

[38] Schmitz S., Pfaffl M.W., Meyer H.H., Bruckmaier R.M., Short-term changes of mRNA expression of various inflammatory factors and milk proteins in mammary tissue during LPS-induced mastitis, Domest. Anim. Endocrinol. (2004) 26:111-126.

[39] Schroder J.M., Epithelial antimicrobial peptides: innate local host response elements, Cell. Mol. Life Sci. (1999) 56:32-46.

[40] Schukken Y.H., Leslie K.E., Barnum D.A., Mallard B.A., Lumsden J.H., Dick P.C., Vessie G.H., Kehrli M.E., Experimental Staphylococcus aureus intramammary challenge in late lactation dairy cows: quarter and cow effects determining the probability of infection, J. Dairy Sci. (1999) 82:2393-2401.

[41] Schukken Y.H., Mallard B.A., Dekkers J.C., Leslie K.E., Stear M.J., Genetic impact on the risk of intramammary infection following Staphylococcus aureus challenge, J. Dairy Sci. (1994) 77:639-647.

[42] Seyfert H.M., Sawatzki G., An estimation of the soluble tubulin content in tetrahymena cells of normal and of size-altered phenotype, Exp. Cell Res. (1986) 162:86-96.

[43] Shoshani E., Leitner G., Hanochi B., Saran A., Shpigel N.Y., Berman A., Mammary infection with Staphylococcus aureus in cows: progress from inoculation to chronic infection and its detection, J. Dairy Res. (2000) 67:155-169.

[44] Shuster D.E., Harmon R.J., Lactating cows become partially refractory to frequent intramammary endotoxin infusions: recovery of milk yield despite a persistently high somatic cell count, Res. Vet. Sci. (1991) 51:272-277.

[45] Shuster D.E., Lee E.K., Kehrli M.E. Jr, Bacterial growth, inflammatory cytokine production, and neutrophil recruitment during coliform mastitis in cows within ten days after calving, compared with cows at midlactation, Am. J. Vet. Res. (1996) 57:1569-1575.

[46] Sinistro A., Ciaprini C., Natoli S., Sussarello E., Carducci F.C., Almerighi C., Capozzi M., Bolacchi F., Rocchi G., Bergamini A., Lipopolysaccharide desensitizes monocytes-macrophages to CD40 ligand stimulation, Immunology (2007) 122:362-370.

[47] Smith K.L., Hogan J.S., Environmental mastitis, Vet. Clin. North Am. Food Anim. Pract. (1993) 9:489498.

[48] Strandberg Y., Gray C., Vuocolo T., Donaldson L., Broadway M., Tellam R., Lipopolysaccharide and lipoteichoic acid induce different innate immune responses in bovine mammary epithelial cells, Cytokine (2005) 31:72-86.

[49] Sutra L., Poutrel B., Virulence factors involved in the pathogenesis of bovine intramammary infections due to Staphylococcus aureus, J. Med. Microbiol. (1994) 40:79-89.

[50] Swanson K., Gorodetsky S., Good L., Davis S., Musgrave D., Stelwagen K., Farr V., Molenaar A., Expression of a beta-defensin mRNA, lingual antimicrobial peptide, in bovine mammary epithelial tissue is induced by mastitis, Infect. Immun. (2004) 72:73117314

[51] Takeda Y., Watanabe H., Yonehara S., Yamashita T., Saito S., Sendo F., Rapid acceleration of neutrophil apoptosis by tumor necrosis factor-alpha, Int. Immunol. (1993) 5:691-694.

[52] Underhill D.M., Ozinsky A., Toll-like receptors: key mediators of microbe detection, Curr. Opin. Immunol. (2002) 14:103-110.

[53] Van Leeuwen W.B., Melles D.C., Alaidan A., Al-Ahdal M., Boelens H.A., Snijders S.V., Wertheim H., van Duijkeren E., Peeters J.K., van der Spek P.J., Gorkink R., Simons G., Verbrugh H.A., van Belkum A., Host- and tissue-specific pathogenic traits of Staphylococcus aureus, J. Bacteriol. (2005) 187:45844591 .

[54] Van Oostveldt K., Tomita G.M., Paape M.J., Capuco A.V., Burvenich C., Apoptosis of bovine neutrophils during mastitis experimentally induced with Escherichia coli or endotoxin, Am. J. Vet. Res. (2002) 63:448-453.

[55] Vangroenweghe F., Duchateau L., Burvenich C., Moderate inflammatory reaction during experimental Escherichia coli mastitis in primiparous cows, J. Dairy Sci. (2004) 87:886-895.

[56] Vanselow J., Yang W., Herrmann J., Zerbe H., Schuberth H.J., Petzl W., Tomek W., Seyfert 
H.M., DNA-remethylation around a STAT5-binding enhancer in the alphaS1-casein promoter is associated with abrupt shutdown of alphaS1-casein synthesis during acute mastitis, J. Mol. Endocrinol. (2006) 37:463477.

[57] Vora P., Youdim A., Thomas L.S., Fukata M., Tesfay S.Y., Lukasek K., Michelsen K.S., Wada A., Hirayama T., Arditi M., Abreu M.T., Beta-defensin-2 expression is regulated by TLR signaling in intestinal epithelial cells, J. Immunol. (2004) 173:5398-5405.

[58] Wellnitz O., Kerr D.E., Cryopreserved bovine mammary cells to model epithelial response to infection, Vet. Immunol. Immunopathol. (2004) 101:191202.

[59] Werling D., Piercy J., Coffey T.J., Expression of toll-like receptors (TLR) by bovine antigen-presenting cells-potential role in pathogen discrimination? Vet. Immunol. Immunopathol. (2006) 112:2-11.

[60] Wolfs T.G., Buurman W.A., van Schadewijk A., de Vries B., Daemen M.A., Hiemstra P.S., van 't Veer C., In vivo expression of toll-like receptor 2 and 4 by renal epithelial cells: IFN-gamma and TNF-alpha mediated up-regulation during inflammation, J. Immunol. (2002) 168:1286-1293.

[61] Yang W., Molenaar A., Kurts-Ebert B., Seyfert H.M., NF-kappaB factors are essential, but not the switch, for pathogen-related induction of the bovine beta-defensin 5-encoding gene in mammary epithelial cells, Mol Immunol (2006) 43:210-225.

[62] Yang W., Zerbe H., Petzl W., Brunner R.M., Günther J., Draing C., von Aulock S., Schuberth H.J., Seyfert H.M., Bovine TLR2 and TLR4 properly transduce signals from $S$. aureus and E. coli, but $S$. aureus fails to both activate NF-kappa $\mathrm{B}$ in mammary epithelial cells and to quickly induce TNF-alpha and Interleukin-8 (CXCL8) expression in the udder, Mol. Immunol. (2007) DOI:10.1016/j.molimm.2007.09.004.

[63] Zasloff M., Antimicrobial peptides of multicellular organisms, Nature (2002) 415:389-395. 